\title{
Retraction Note: Increased survival and cell cycle progression pathways are required for EWS/FLI1-induced malignant transformation
}

Tahereh Javaheri, ${ }^{1,2}$, Zahra Kazemi ${ }^{3,4}$, Jan Pencik ${ }^{1,3,5}$, Ha T. T. Pham ${ }^{1,2}$, Maximilian Kauer ${ }^{6}$, Rahil Noorizadeh ${ }^{1,2}$, Barbara Sax ${ }^{1}$, Harini Nivarthi ${ }^{1,7}$, Michaela Schlederer ${ }^{1,3,5}$, Barbara Maurer ${ }^{1,2}$, Maximillian Hofbauer ${ }^{1}$, Dave N. T. Aryee ${ }^{6,8}$, Marc Wiedner ${ }^{1,7}$, Eleni M. Tomazou ${ }^{6}$, Malcolm Logan ${ }^{9}$, Christine Hartmannn ${ }^{10}$, Jan P. Tuckermann ${ }^{11}$, Lukas Kenner ${ }^{1,3,5,12}$, Mario Mikula ${ }^{3,13}$, Helmut Dolznig ${ }^{3,13}$, Aykut Üren ${ }^{14}$, Günther H. Richter ${ }^{15}$, Florian Grebien ${ }^{1}$, Heinrich Kovar ${ }^{6,8}$ and Richard Moriggl $\left.\right|^{1,2,3}$

\section{Retraction Note to: Cell Death \& Disease https://doi.org/10.1038/cddis.2016.268 Published online 13 Oct 2016}

The authors have retracted this article because in Supplementary Figure $8 \mathrm{~b}(1)$ the left-hand and right-hand MCL1 blots are the same, and (2) the cleaved caspase-3 blot lane 5 in the left panel is a duplicate of the first lane of the cleaved caspase- 3 blot in the middle panel. Authors

\footnotetext{
Correspondence: Richard Moriggl (richard.moriggl@lbicr.lbg.ac.at)

${ }^{1}$ Ludwig Boltzmann Institute for Cancer Research, Vienna, Austria

${ }^{2}$ Institute of Animal Breeding and Genetics, University of Veterinary Medicine, Vienna, Austria

${ }^{3}$ Medical University of Vienna, Vienna, Austria

${ }^{4}$ Center of Physiology and Pharmacology, Vienna, Austria

${ }^{5}$ Clinical Institute of Pathology, Vienna, Austria

${ }^{6}$ Children's Cancer Research Institute, St. Anna Kinderkrebsforschung, Vienna,

Austria

${ }^{7}$ CeMM Research Center for Molecular Medicine of the Austrian Academy of

Sciences, Vienna, Austria

${ }^{8}$ Department of Pediatrics, Medical University of Vienna, Vienna, Austria

${ }^{9}$ Randall Division of Cell and Molecular Biophysics, King's College London,

London, UK

${ }^{10}$ Department of Bone and Skeletal Research, Institute of Experimental

Musculoskeletal Medicine, University Hospital Münster, Münster, Germany

${ }^{11}$ Institute of General Zoology and Endocrinology, University of UIm, UIm,

Germany

${ }^{12}$ University of Veterinary Medicine, Vienna, Austria

${ }^{13}$ Institute of Medical Genetics, Vienna, Austria

${ }^{14}$ Georgetown University Medical Center, Lombardi Comprehensive Cancer

Center, Washington, USA

${ }^{15}$ Children's Cancer Research Centre and Department of Pediatrics, Klinikum

rechts der Isar, Technische Universität München, Munich, Germany
}

M. Hofbauer, M. Wiedner, C. Hartman, J. Tuckerman, J. Pencik, E. Tomazou, M. Schlederer, T. Javaheri, M. Mikula, H. Nivarthi, L. Kenner, D. Aryee, B. Sax, F. Grebien, H. Dolznig, G. Richter, M. Logan, B. Maurer, A. Üren, H. Kovar, R. Morrigl, and H. Pham agree with the retraction. Authors Z. Kazemi, M. Kauer, and R. Noorizadeth have not responded to correspondence about this retraction. The authors are repeating their experiments and a new manuscript will be submitted for peer review.

Published online: 13 August 2019

\section{(c) The Author(s) 2019}

(c) (i) Open Access This article is licensed under a Creative Commons Attribution 4.0 International License, which permits use, sharing, adaptation, distribution and reproduction cc) in any medium or format, as long as you give appropriate credit to the original author(s) and the source, provide a link to the Creative Commons license, and indicate if changes were made. The images or other third party material in this article are included in the article's Creative Commons license, unless indicated otherwise in a credit line to the material. If material is not included in the article's Creative Commons license and your intended use is not permitted by statutory regulation or exceeds the permitted use, you will need to obtain permission directly from the copyright holder. To view a copy of this license, visit http://creativecommons.org/licenses/by/4.0/. 